\title{
Antimony Ore Tailings: Heavy Metals, Chemical Speciation, and Leaching Characteristics
}

\author{
Yingying Zhou ${ }^{1,2}$, Bozhi Ren ${ }^{1,2 *}$, Andrew S Hursthouse ${ }^{1,3}$, Saijun Zhou ${ }^{2}$ \\ ${ }^{1}$ Hunan Provincial Key Laboratory of Shale Gas Resource Exploitation, Xiangtan, China \\ ${ }^{2}$ School of Civil Engineering, Hunan University of Science and Technology, Xiangtan, China \\ ${ }^{3}$ School of Science and Sport, University of the West of Scotland, Paisley, United Kingdom
}

Received: 3 December 2017

Accepted: 2 February 2018

\begin{abstract}
Antimony ore tailings slag was used analyze heavy metals, chemical speciation, and leaching characteristics. The results show that the residual silicate phases account for $65.44 \%$ of $\mathrm{Sb}, 77.22 \%$ of As, $87.94 \%$ of $\mathrm{Hg}, 58.53 \%$ of $\mathrm{Pb}, 71.27 \%$ of $\mathrm{Cd}$, and $96.34 \%$ of $\mathrm{Zn}$. Although the exchangeable and carbonate phases account for $7.71 \%$ of $\mathrm{Sb}, 0.71 \%$ of $\mathrm{As}, 3.77 \%$ of $\mathrm{Hg}, 4.82 \%$ of $\mathrm{Pb}, 1.83 \%$ of $\mathrm{Cd}$, and $1.73 \%$ of $\mathrm{Zn}$, the water-or-acid-soluble phases contribute more to the chemical speciation of heavy metals. Concentrations of $\mathrm{Sb}$, As, and $\mathrm{Hg}$ in the leachates increased with increasing solid-liquid ratio, decreasing particle size and increasing temperature. In simulated rainfall conditions, the total quantity increased in the order $\mathrm{Sb}>\mathrm{As}>\mathrm{Hg}$ and were $42.508 \mathrm{mg}, 52.940 \mu \mathrm{g}$, and $0.876 \mu \mathrm{g}$, respectively, at $500 \mathrm{~g}$ antimony ore tailings. Under different rainfall intensity simulations, the maximum quantity in the leachates of $\mathrm{Sb}$, As, and $\mathrm{Hg}$ were $93.894 \mathrm{mg}, 255.451 \mu \mathrm{g}$, and $1.690 \mu \mathrm{g}$, respectively, and increased in the order of moderate $>$ heavy > rainstorm. Finally, the cumulative leaching of Sb at pH 6.0 is $42.025 \mathrm{mg} / \mathrm{L}$ (higher than at 4.0 and 5.0), and the As and $\mathrm{Hg}$ at $\mathrm{pH} 4.0$ are $107.097 \mu \mathrm{g} / \mathrm{L}$ and $0.989 \mu \mathrm{g} / \mathrm{L}$, respectively.
\end{abstract}

Keywords: antimony ore tailings, heavy metals, speciation, leaching

\section{Introduction}

Typically, tailings, as solid waste, are discharged into rivers or are contained in tailing dams. Antimony ore tailings contain $\mathrm{Sb}, \mathrm{As}, \mathrm{Hg}$, and other heavy metals [1-4] that are highly toxic [5-7]. Previous reports have shown that the majority of heavy metals pollution appears to originate from mining and industry, because very high levels of pollution have been detected around tailings [8-11]. The pollution of heavy metals in the

*e-mail: yingyzhouq@163.com aquatic environment results from rock weathering, soil runoff, and anthropogenic activities. The heavy metals in antimony ore tailings slowly precipitate into the soil and pollute surrounding areas, threatening the health and safety of humans and animals [12-15].

Presently, the leaching behavior of heavy metals in slag is based on static and dynamic leaching laboratory tests. Biver and Shotyk [16-17] derived an equation to describe the release of $\mathrm{Sb}$ from studying stibliconite, senarmontite, and valentinite ores and derived an empirical equation of the release of $\mathrm{Sb}$ from stiblite $\left(\mathrm{Sb}_{2} \mathrm{~S}_{3}\right)$. Zhang et al. [18] demonstrated that ultrasonic treatment can significantly shorten the time $\mathrm{Sb}$ and $\mathrm{Pb}$ 
reach equilibrium in leaching tests of tailing slags. $\mathrm{Hu}$ et al. [10] found no significant correlation between $\mathrm{Sb}$, $\mathrm{As}, \mathrm{Pb}$, and $\mathrm{Cr}$ leaching and heavy metals content in ores based on static leaching tests with acid solutions ( $\mathrm{pH}$ $=2$ ). Ren et al. [19-20] studied the leaching of Sb by static and dynamic leaching tests of antimony smelting slag. As we know, in the natural environment the oxidative dissolution of abundant sulfide ore leads to the net release of protons, a phenomenon known as acid mine or acid rock drainage [21-24]. Therefore, it is great significant to study the heavy metals, chemical speciation, and leaching characteristics in antimony ore tailings.

As the world's largest antimony (Sb) producer, China produces on average $80 \%$ of global $\mathrm{Sb}$ annually. Xikuangshan in Hunan, the world's largest $\mathrm{Sb}$ mine, is reported to produce $25 \%$ of the world's total [25]. The Xikuangshan mine has been mining for almost 120 years. Its longtime and large-scale mining has produced a large tailings storehouse. Harmful elements like Sb, $\mathrm{As}$, and $\mathrm{Hg}$ have been released with surface runoff and precipitation infiltration, threatening the environment and human beings. Some reports shown that high $\mathrm{Sb}$ concentration in water (up to $29.4 \mathrm{mg} / \mathrm{L}$ ), sediments (up to $1,163 \mathrm{mg} / \mathrm{kg}$ ), and soils (up to $5,045 \mathrm{mg} / \mathrm{kg}$ ) were found near Xikuangshan mining and smelting areas in China [26-28]. At present, the research mainly focuses on the removal of heavy metals in wastewater and the impact on the surrounding environment [29-32], but few have paid attention to the characteristics of metal dissolution in tailings and accumulated empirical equations. In this study, antimony ore tailings were studied with respect to heavy metals content, chemical speciation, and leaching characteristics to understand the leaching of heavy metals and derive accumulated empirical equations. It aims to provide theoretical support for the discharge and stockpiling of $\mathrm{Sb}, \mathrm{As}$, and $\mathrm{Hg}$, etc., metal(loid) pollution control, and environmental monitoring. Other nonferrous mining areas can learn from research methods and conclusions

\section{Materials and Methods}

\section{Materials}

The antimony ore tailings were from the Lengshuijiang Xikuangshan Mine in China. The samples were air-dried and mixed, pulverized, and screened using nylon sieves with openings $(20,40,60$, and 100 mesh).

\section{Equipment and Methods}

\section{Speciation of Heavy Metals in Tailings}

Metals in solid waste are associated with exchangeable (dissolved) cations, carbonates, Fe-Mn oxides, organic matter-sulfides complexes, and mineral residue [33]. In this study we used hydride generation atomic fluorescence spectrometry (HG-AFS) to determine the heavy metals in the tailings, and modified Tessier sequential extraction [34] was used to examine the speciation of heavy metals.

\section{Heavy Metals in Tailings}

Antimony ore tailings with particle size less than 100 mesh were weighed with precision of $0.1 \mathrm{~g}$ into polytetrafluoroethylene digestion tanks, with $5 \mathrm{~mL}$ $\mathrm{HNO}_{3}$ and $0.5 \mathrm{~mL} \mathrm{HF}$, and placed in an oven at $170^{\circ} \mathrm{C}$ for $12 \mathrm{~h}$. Next, one $\mathrm{mL} 30 \% \mathrm{H}_{2} \mathrm{O}_{2}$ was added, and the solution was left to cool for $30 \mathrm{~min}$; finally, $10 \mathrm{~mL}$ $5 \% \mathrm{HNO}_{3}$ was added. The sample was then filtered in a tubular filter with a $0.2-\mu \mathrm{m}$ polyethylene film, and ultrapure water $(18.0 \mathrm{M} \Omega . \mathrm{cm})$ was added up to $50 \mathrm{~mL}$. The heavy metals were measured by HG-AFS (AFS - 9700, Beijing Haiguang).

\section{Static Leaching Experiments}

The reactors were $1,000-\mathrm{mL}$ glass bottles. The supernatant was extracted every $24 \mathrm{~h}$, filtered in a tubular filter with $0.2-\mu \mathrm{m}$ polyethylene film, and the filtrate was analyzed by HG-AFS. All the experiments were performed in duplicate and with procedural blanks. The test periods were 12 days.

Antimony ore tailings with particle size more than 100 mesh were weighed (100, 50, and $25 \mathrm{~g})$ and placed in the reactors with $500-\mathrm{mL}$ ultrapure water. The $\mathrm{pH}$ of the solutions was adjusted to 7.0. The supernatant was extracted every $24 \mathrm{~h}$. The concentration of heavy metals and the $\mathrm{pH}$ in the supernatant was measured at different soaking times and solid-liquid ratios (1:5, 1:10, 1:20).

Samples (50 g) with particle size of $>100$ mesh, 40-100 mesh, and 20-40 mesh were placed in the reactors with 500-mL ultrapure water (solid-liquid ratio of 1:10). The supernatant was extracted every $24 \mathrm{~h}$. The concentration of heavy metals in the supernatant was measured at different soaking times.

Samples $(50 \mathrm{~g})$ with particle size $>100$ mesh were placed in the reactors with $500 \mathrm{~mL}$ ultrapure water (solid-liquid ratio of 1:10). The reactors were placed in a thermostatic chamber at $15^{\circ} \mathrm{C}, 25^{\circ} \mathrm{C}$, and $35^{\circ} \mathrm{C}$ at different soaking times.

\section{Dynamic Leaching Experiments}

The leaching columns were polymethyl methacrylate tubes (Fig. 1) loaded from the bottom to the top in the following sequence: filter, fabrics, 50 -mm-thick quartz sand (1-5 mm particle size), and $500 \mathrm{~g}$ of ore sample. The leaching columns were gently vibrated to compact the samples. Then a filter layer was placed on top of the sample to evenly distribute the water during leaching. Finally, $500 \mathrm{~mL}$ of ultrapure water was added and the entire setup was left to dry for $24 \mathrm{~h}$. The leaching solution was $\mathrm{H}_{2} \mathrm{SO}_{4}: \mathrm{HNO}_{3}(3: 1 \mathrm{v} / \mathrm{v})$ mixed with $\mathrm{NaOH}$ at different $\mathrm{pH}$ values to model various acid rain conditions. The test period was 12 days. 


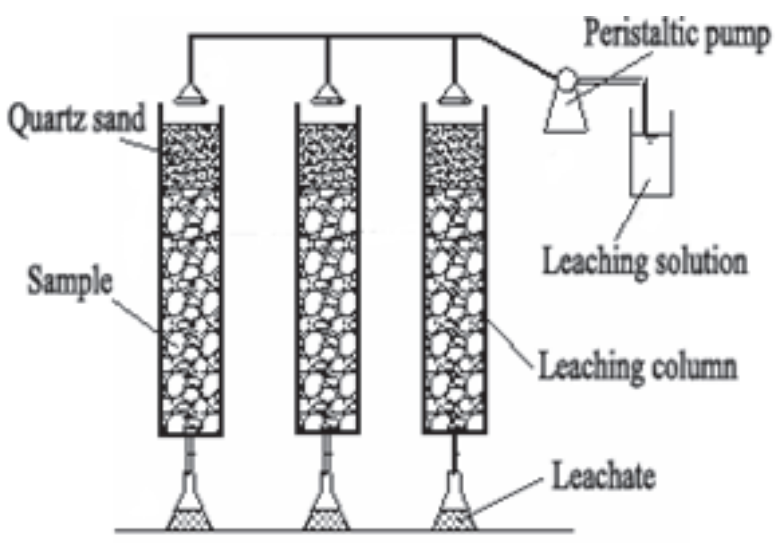

Fig. 1. Experimental setup in the dynamic leaching experiments.

The average rainfalls from January to December were 95, 98, 162, 224, 315, 324, 197, 185, 104, 110, 99, and $72 \mathrm{ml} / \mathrm{month}$. One day's rainfall simulates a month's rainfall, the leaching solution $(\mathrm{pH} 5.0)$ was added by using a peristaltic pump and flow rate of $30 \mathrm{~mL} / \mathrm{h}$. Finally, the leaching solution was collected and the heavy metals concentration was measured.

To simulate the effect of rainfall intensity on leaching, leaching solution ( $\mathrm{pH}$ 5.0) was daily added using a peristaltic pump up to $287 \mathrm{~mL}$. The leaching rate was 60 , 120 , and $180 \mathrm{~mL} / \mathrm{h}$ to simulate rainstorm, heavy rain, and moderate rain, respectively. Finally, the leaching solution was collected and the heavy metals concentration was measured.

To simulate the effect of variable $\mathrm{pH}$ on leaching and the release of heavy metals, $165 \mathrm{~mL}$ (monthly mean rainfall) of leaching solution with $\mathrm{pH}$ values of 4.0, 5.0 , and 6.0 at flow rate of $60 \mathrm{~mL} / \mathrm{h}$ was added daily using a peristaltic pump. Finally, the leaching solution was collected and the heavy metals and $\mathrm{pH}$ were measured.

\section{Analysis}

The concentration of $\mathrm{Sb}$ was determined by flame atomic absorption spectrophotometry (AA-7002A, Beijing Sanxiong) when the concentration of $\mathrm{Sb}$ was greater than $0.5 \mathrm{mg} / \mathrm{L}$. The concentrations of $\mathrm{As}, \mathrm{Hg}$, and $\mathrm{Sb}$ (the concentration of $\mathrm{Sb}$ was below $0.5 \mathrm{mg} / \mathrm{L}$ ) were determined by HG-AFS (AFS-9700, Beijing Haiguang). The $\mathrm{pH}$ of the leaching solution was measured using a $\mathrm{pH}$ meter (PB-10, Germany). The structure, morphology, and composition of antimony ore tailings before and

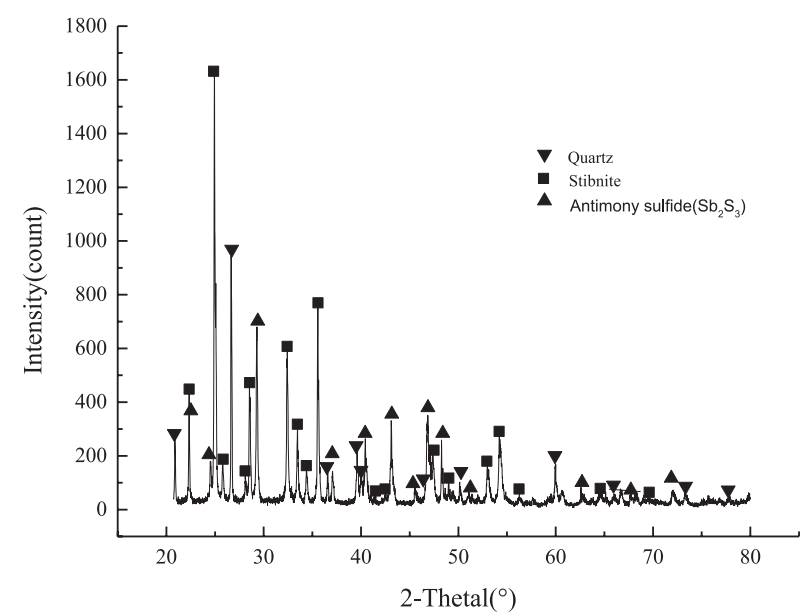

Fig. 2. XRD patterns of ore tailings.

after the static and dynamic leaching experiments were observed by transmission electron microscopy (JEOL JEM-2800, Japan), x-ray diffraction (XRD, SMART APEX, Germany), and the conditions of XRD were $\mathrm{Cu}$ $\mathrm{K}_{\lambda}$ radiation, $40 \mathrm{kV}$, and $40 \mathrm{~mA}, 2$ theta range $10-80^{\circ}$ with a scan rate step of $0.05 \%$, and energy-dispersive spectroscopy (GENESIS, USA).

\section{Results and Discussion}

\section{Phase Composition}

The XRD patterns of the tailings were shown in Fig. 2 . The results show that the antimony ore tailings mainly include stibnite, antimony sulfide, and quartz. Other minerals may not be detected because of the low content.

\section{Heavy Metals in Tailings}

The situation of heavy metal in tailings samples are given in Table 1. Five heavy metals exceed the background values.

\section{Chemical Speciation}

The elements of $\mathrm{Sb}, \mathrm{As}, \mathrm{Hg}, \mathrm{Pb}, \mathrm{Cd}$, and $\mathrm{Zn}$ in antimony ore tailings were analyzed by the modified Tessier sequential extraction and the results are shown in Table 2. The bioavailability of heavy metal elements is closely related to chemical speciation. High

Table 1 . Heavy metal content in antimony tail slag $(\mathrm{mg} / \mathrm{kg})$.

\begin{tabular}{|c|c|c|c|c|c|c|}
\hline Heavy metal & $\mathrm{Sb}$ & $\mathrm{As}$ & $\mathrm{Hg}$ & $\mathrm{Pb}$ & $\mathrm{Cd}$ & $\mathrm{Zn}$ \\
\hline Contents & $2,570.43$ & 984.25 & 3.11 & 19.18 & 2.08 & 577.35 \\
\hline Background values & 2.98 & 14 & 0.09 & 27 & 0.079 & 95 \\
\hline Excess multiples & 863 & 70 & 35 & -- & 26 & 6 \\
\hline
\end{tabular}


Table 2. Results of chemical speciation analysis for $\mathrm{Sb}, \mathrm{As}, \mathrm{Hg}, \mathrm{Pb}, \mathrm{Cd}$, and $\mathrm{Zn}(\mathrm{mg} / \mathrm{kg}$ ).

\begin{tabular}{|c|c|c|c|c|c|c|c|c|c|c|c|c|}
\hline \multicolumn{13}{|c|}{ Antimony ore tailings } \\
\hline & \multicolumn{2}{|c|}{$\mathrm{Sb}$} & \multicolumn{2}{|c|}{ As } & \multicolumn{2}{|c|}{$\mathrm{Hg}$} & \multicolumn{2}{|c|}{$\mathrm{Pb}$} & \multicolumn{2}{|c|}{$\mathrm{Cd}$} & \multicolumn{2}{|c|}{$\mathrm{Zn}$} \\
\hline & $\begin{array}{c}\text { Concen- } \\
\text { tration }\end{array}$ & $\%$ & $\begin{array}{c}\text { Concen- } \\
\text { tration }\end{array}$ & $\%$ & $\begin{array}{c}\text { Concen- } \\
\text { tration }\end{array}$ & $\%$ & $\begin{array}{c}\text { Concen- } \\
\text { tration }\end{array}$ & $\%$ & $\begin{array}{c}\text { Concen- } \\
\text { tration }\end{array}$ & $\%$ & $\begin{array}{c}\text { Concen- } \\
\text { tration }\end{array}$ & $\%$ \\
\hline $\begin{array}{l}\text { Exchange } \\
\text { cations }\end{array}$ & 47.30 & 1.84 & 4.33 & 0.44 & 0.04 & 1.29 & 0.092 & 0.48 & 0.026 & 1.27 & 6.75 & 1.17 \\
\hline Carbonates & 150.88 & 5.87 & 2.66 & 0.27 & 0.077 & 2.48 & 0.832 & 4.34 & 0.012 & 0.56 & 3.23 & 0.56 \\
\hline Fe-Mn oxides & 111.810 & 4.35 & 63.09 & 6.41 & 0.033 & 1.07 & 2.098 & 10.94 & 0.119 & 5.74 & 5.02 & 0.87 \\
\hline $\begin{array}{c}\text { Organic } \\
\text { matter-sulfide } \\
\text { complexes }\end{array}$ & 578.35 & 22.5 & 154.13 & 15.66 & 0.225 & 7.22 & 4.931 & 25.71 & 0.44 & 21.16 & 6.136 & 1.06 \\
\hline Residue & $1,682.09$ & 65.44 & 760.04 & 77.22 & 2.735 & 87.94 & 11.226 & 58.53 & 1.483 & 71.27 & 556.22 & 96.34 \\
\hline Total & $2,570.43$ & 100 & 984.25 & 100 & 3.11 & 100 & 19.18 & 100 & 2.08 & 100 & 577.35 & 100 \\
\hline
\end{tabular}

bioavailability included water-soluble and exchangeable phases; moderate bioavailability included carbonates, Fe-Mn oxides, and organic matter-sulfide complexes. Low bioavailability included residual phases, typically

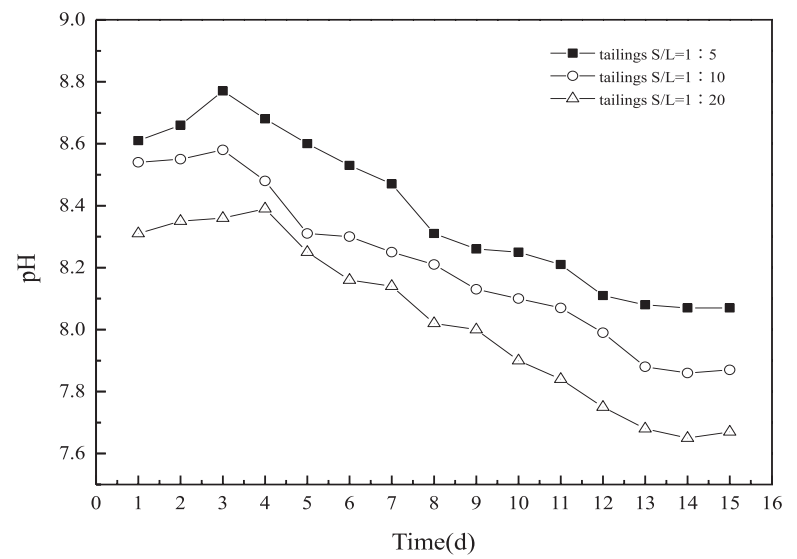

Fig. 3. Slag pH vs. time at different solid-liquid ratios.

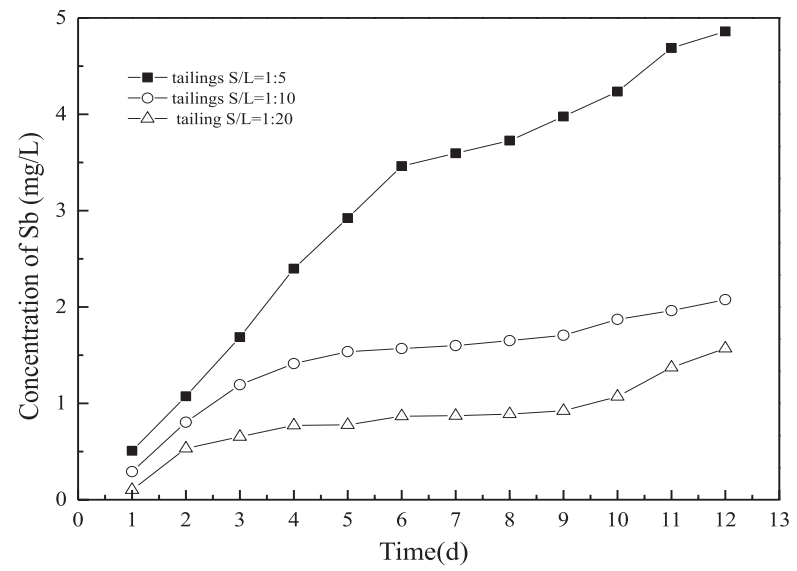

Fig. 4. Sb concentrations in leachate vs. time at different solidliquid ratios. silicates. In the tailings, the exchangeable and carbonate phases mostly contributed to the leachates [33].

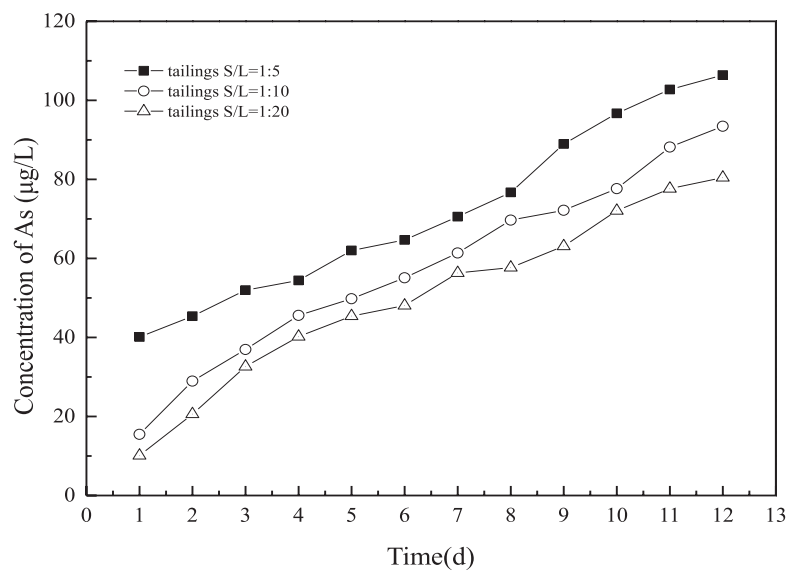

Fig. 5. As concentrations in leachate vs. time at different solidliquid ratios.

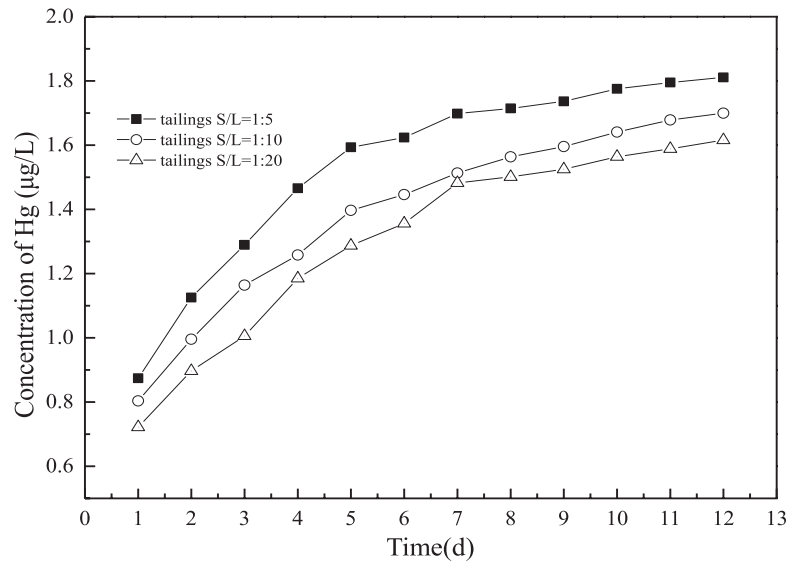

Fig. 6. Hg concentrations in leachate vs. time at different solidliquid ratios. 
In the tailings, the residual silicate phases account for $65.44 \%$ of $\mathrm{Sb}, 77.22 \%$ of $\mathrm{As}, 87.94 \%$ of $\mathrm{Hg}, 58.53 \%$ of $\mathrm{Pb}, 71.27 \%$ of $\mathrm{Cd}$, and $96.34 \%$ of $\mathrm{Zn}$. The exchangeable and carbonate phases account for $7.71 \%$ of $\mathrm{Sb}, 0.71 \%$

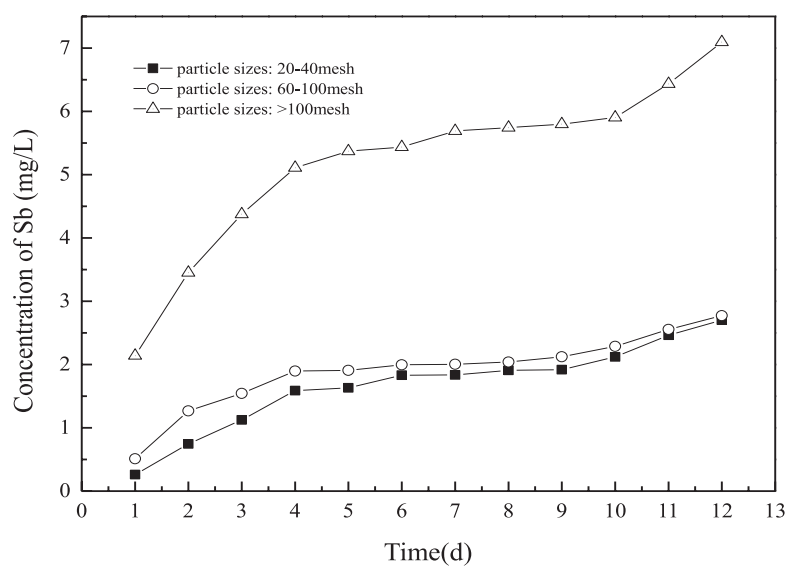

Fig. 7. Sb concentrations in the leachate vs. time at different particle sizes.

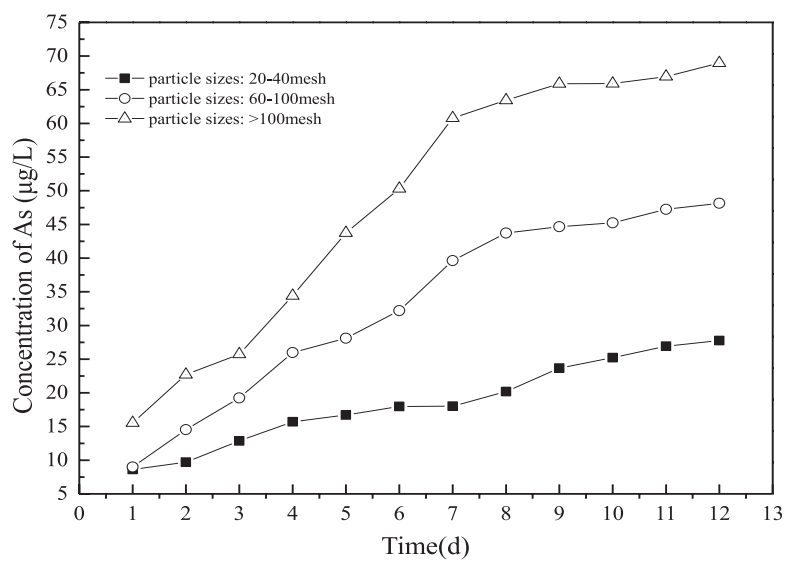

Fig. 8. As concentrations in the leachate vs. time at different particle sizes.

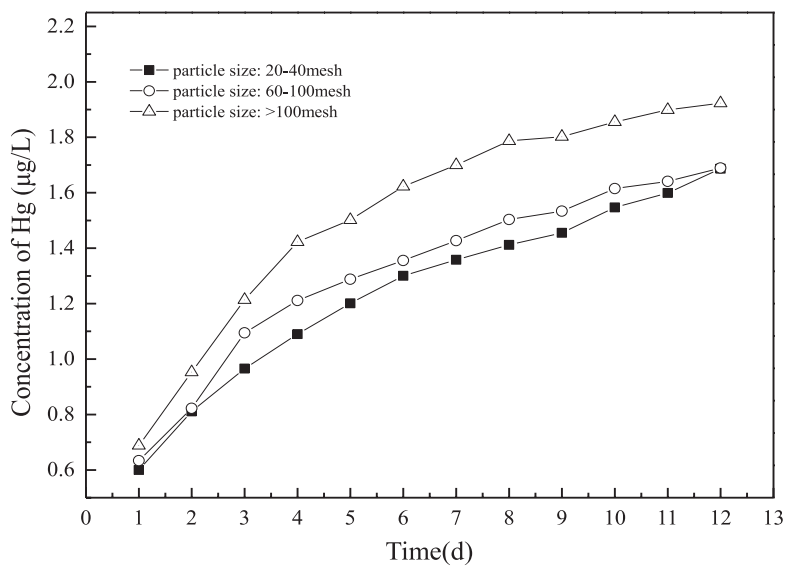

Fig. 9. Hg concentrations in the leachate vs. time at different particle sizes. of $\mathrm{As}, 3.77 \%$ of $\mathrm{Hg}, 4.82 \%$ of $\mathrm{Pb}, 1.83 \%$ of $\mathrm{Cd}$, and $1.73 \%$ of $\mathrm{Zn}$. Although the proportion of exchangeable and carbonate phases in tailings was small, the wateror acid-soluble phases contributed more to the chemical speciation of heavy metals and produced a lot of pollution. Various forms would be transformed into each other [35].

\section{Release of Heavy Metals}

The release characteristics of heavy metals in antimony ore tailings under different solid-liquid ratio, particle size, leaching $\mathrm{pH}$ value, rainfall intensity and other condition were studied by dynamic and static leaching test. Accumulated empirical equations of heavy metals were established with different $\mathrm{pH}$ and different rainfall intensities.

\section{Solid-Liquid Ratio and Dissolution of $\mathrm{Sb}, \mathrm{As}$, and $\mathrm{Hg}$}

The $\mathrm{pH}$ and concentrations of $\mathrm{Sb}, \mathrm{As}$, and $\mathrm{Hg}$ with time at different solid-liquid ratios are shown in Figs 3-6. The soaking solution $\mathrm{pH}$ increased with increasing solidliquid ratios and reached maximum $(\mathrm{pH}>8.0)$ after 3 to 4 days. This may be related to the alkaline composition of tailings, e.g., quartz. Subsequently, $\mathrm{pH}$ gradually decreased with time and then stabilized owing to the formation of $\mathrm{H}_{2} \mathrm{SO}_{4}$ by the degradation of $\mathrm{Sb}_{2} \mathrm{~S}_{3}$ [36].

Figs 4-6 show changes in the concentrations of $\mathrm{Sb}$, $\mathrm{As}$, and $\mathrm{Hg}$ with time. Concentrations of $\mathrm{Sb}$, As, and $\mathrm{Hg}$ in the soaking solution were low with small solidliquid ratios. With increasing solid-liquid ratios, the concentrations of $\mathrm{Sb}, \mathrm{As}$, and $\mathrm{Hg}$ in the soaking solution increased. Dilution was important in the dissolution of heavy metals with decreasing solid-liquid ratios and was responsible for the low concentration of heavy metals. Small solid-liquid ratios may favor the dissolution of insoluble minerals.

The concentration of $\mathrm{Hg}$ in the soaking solution increased with time and stabilized, and the concentrations of $\mathrm{Sb}$ and As increased slowly after 1012 days. Presumably, the process of dissolution started at the surface, then to the interior of the slag and became diffusion-dependent. The main influence factor that affects the analysis of static immersion is hydrolysis oxidation reaction on the waste surface [37].

\section{Particle Size and the Dissolution of $\mathrm{Sb}, \mathrm{As}$, and $\mathrm{Hg}$}

The dissolution of $\mathrm{Sb}, \mathrm{As}$, and $\mathrm{Hg}$ with different particle sizes is shown in Figs 7-9. Heavy metals dissolve faster and their concentrations in the solution were higher with decreasing particle size. The smaller the particle size the greater the surface area, and the greater the surface area in contact with liquid, the faster and more pronounced the dissolution of heavy metals in the tailings. In addition, the smaller the particle size, 
the easier the dissociation of antimony mineral monomers, and thus the greater release of heavy metals into the liquid. With the decrease of particle size, the specific surface area and the reaction contact area increases, which makes the reaction rate accelerate so that the release amount increased [19].

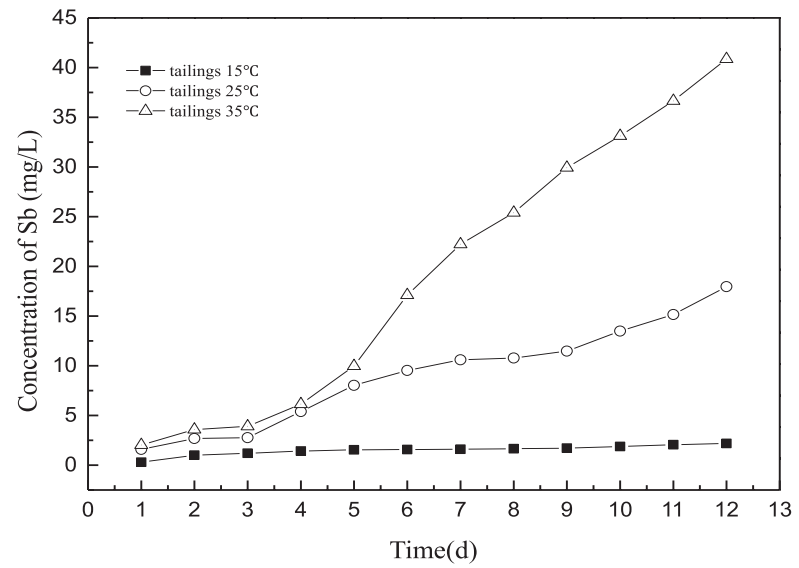

Fig. 10. Sb dissolution vs. time at different temperatures.

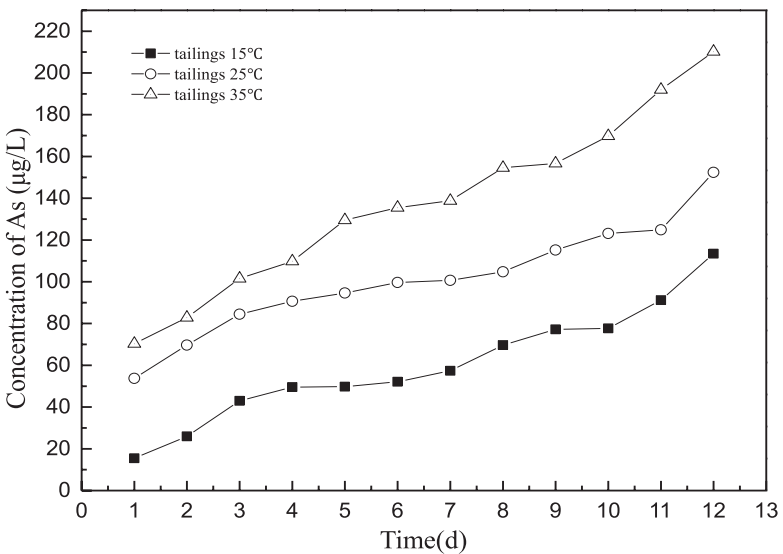

Fig. 11. As dissolution vs. time at different temperatures.

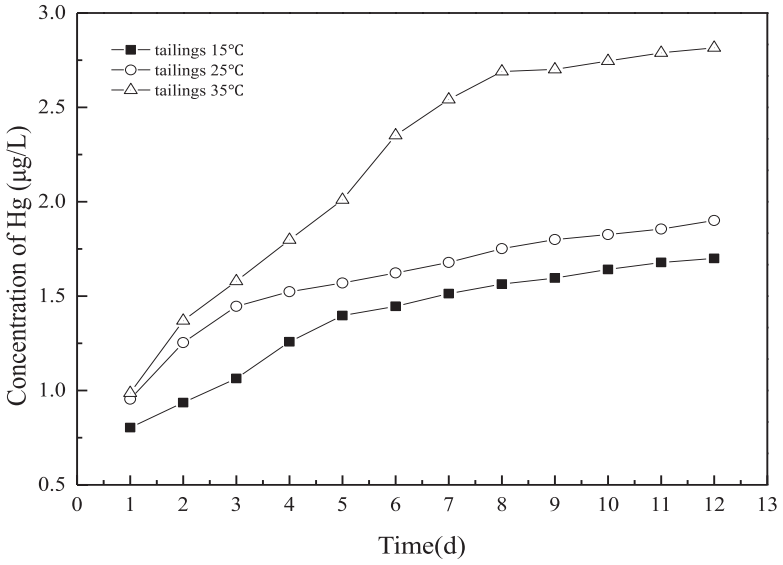

Fig. 12. Hg dissolution vs. time at different temperatures.

\section{Temperature and the Dissolution of $\mathrm{Sb}, \mathrm{As}$, and $\mathrm{Hg}$}

The concentrations of $\mathrm{Sb}, \mathrm{As}$, and $\mathrm{Hg}$ in the soaking solution at different temperatures is shown in Figs 10-12. The process of dissolution was endothermic; therefore, the dissolution of heavy metals was favored by high temperatures. The influence of $\mathrm{Sb}$ and $\mathrm{Hg}$ was stronger than As At $35^{\circ} \mathrm{C}$, whereas the influence was similar for $\mathrm{Sb}, \mathrm{As}$, and $\mathrm{Hg}$ at $15^{\circ} \mathrm{C}$. According to the principle of chemical reaction equilibrium, when the temperature rises, the reaction moves in an endothermic direction.

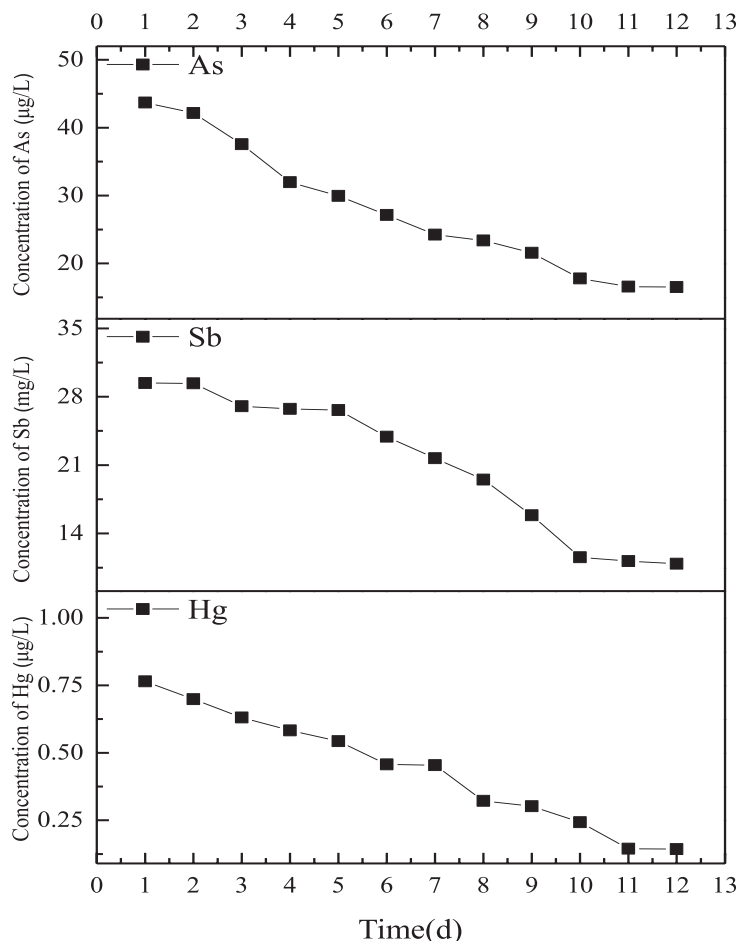

Fig. 13. Concentrations of $\mathrm{Sb}$, $\mathrm{As}$, and $\mathrm{Hg}$ vs. time in the dynamic leaching experiments.

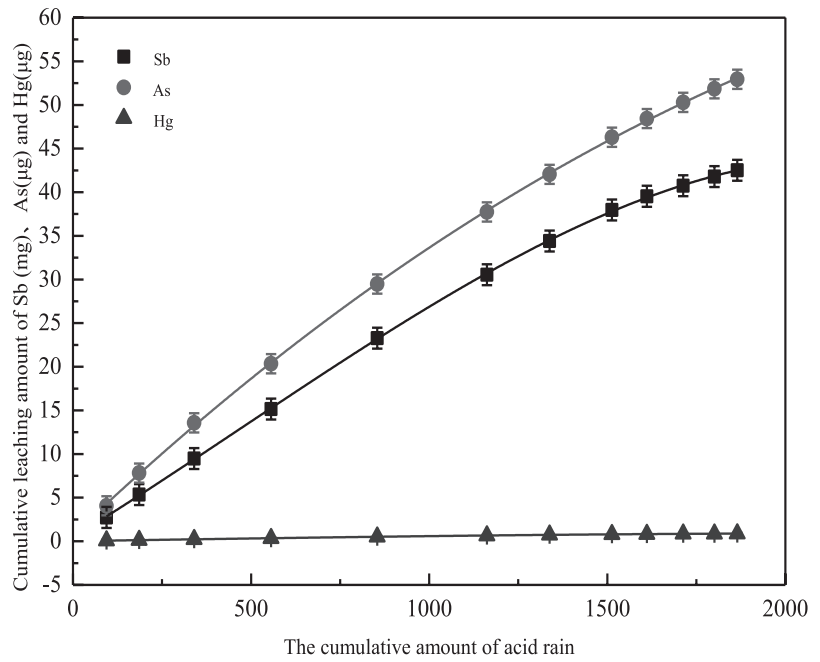

Fig. 14. Cumulative leaching of $\mathrm{Sb}, \mathrm{As}$, and $\mathrm{Hg}$. 
Therefore, heavy metals in antimony mining waste stone are more easily precipitated with higher temperature.

\section{Leaching Characteristic of Sb, As, and Hg}

The concentrations of $\mathrm{Sb}, \mathrm{As}$, and $\mathrm{Hg}$ vs. time in the acid rain simulations are shown in Fig. 13. The dissolution of $\mathrm{Sb}, \mathrm{As}$, and $\mathrm{Hg}$ is high initially and then decreases gradually. The release descending at the start of the leaching time may be because the surface pores of slag are eroded, leading to surface collapse and reduction of the contact area among slag, water, and air. The process of dissolution started at the surface of the particles. The diffusion of heavy metals from the residue to the solution was divided into disassociation from the solid-liquid interface and then dispersion from the solidliquid interface to the solution. The first stage was fast, whereas the second was slow. The prolonged dissolution of heavy metals into the solution depends on diffusion, and the cumulative release is better described by cubic polynomials (Fig. 14).

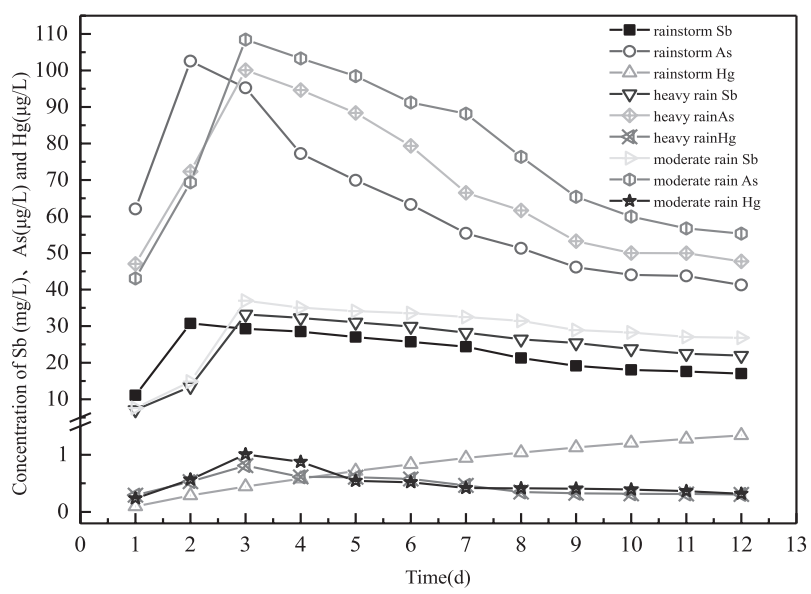

Fig. 15. Leaching behavior of heavy metals in the tailings under different rainfall intensities.

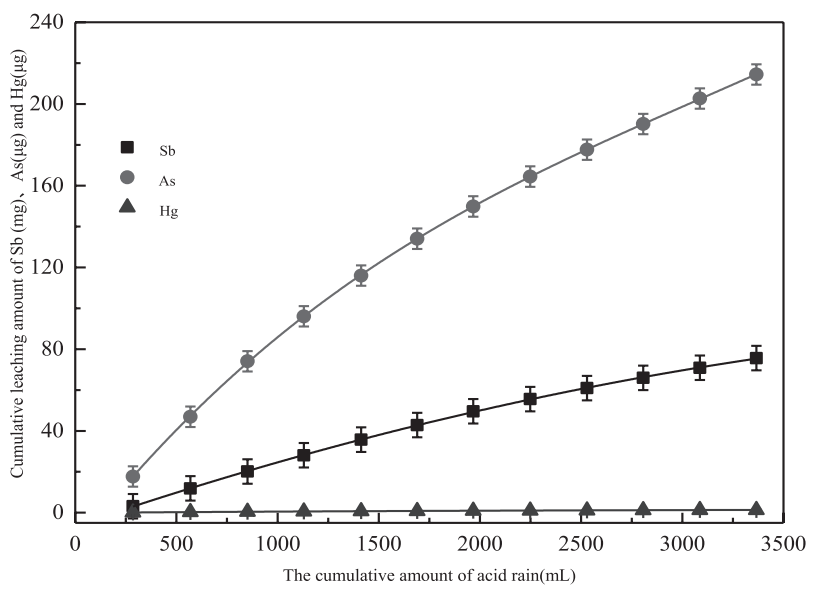

Fig. 16. Cumulative leaching data for $\mathrm{Sb}, \mathrm{As}$, and $\mathrm{Hg}$ during rainstorms.
The total quantity in the leachates increased in the order $\mathrm{Sb}>\mathrm{As}>\mathrm{Hg}$ and were $42.508 \mathrm{mg}, 52.940 \mu \mathrm{g}$, and $0.876 \mu \mathrm{g}$, respectively, at $500 \mathrm{~g}$ antimony ore tailings. In the simulation of one year of acid rain, the concentration of $\mathrm{Sb}$ were $10.909 \mathrm{mg} / \mathrm{L}$, As was $16.528 \mu \mathrm{g} / \mathrm{L}$, and $\mathrm{Hg}$ was $0.133 \mu \mathrm{g} / \mathrm{L}$.

Fitting equation of $\mathrm{Sb}: \mathrm{Y}=0.43978+0.0252 \mathrm{X}+$ $4.28974 \mathrm{E}^{-6} \mathrm{X}^{2}-3.06015 \mathrm{E}^{-9} \mathrm{X}^{3}\left(\mathrm{R}^{2}=0.9999\right)$

Fitting equation of As: $\mathrm{Y}=0.69092+0.03894 \mathrm{X}-$ $6.19734 \mathrm{E}^{-6} \mathrm{X} 2+2.04278 \mathrm{E}^{-10} \mathrm{X}^{3}\left(\mathrm{R}^{2}=0.9998\right)$

Fitting equation of $\mathrm{Hg}$ : $\mathrm{Y}=0.01491+6.30686 \mathrm{E}^{-4} \mathrm{X}-$ $1.37286 \mathrm{E}^{-8} \mathrm{X} 2-4.08827 \mathrm{E}^{-11} \mathrm{X}^{3}\left(\mathrm{R}^{2}=0.9998\right)$.

\section{Leaching Characteristic of Sb, As, and Hg at Different Rainfall Intensities}

The average annual rainfall at Xikuangshan Mine was $1,440 \mathrm{~mm}$, and the monthly rainfall was uneven. In this study, to simulate the rainfall, the average monthly rainfall for Lengshuijiang in 1995-2013 between April and June was considered along with the rainwater runoff

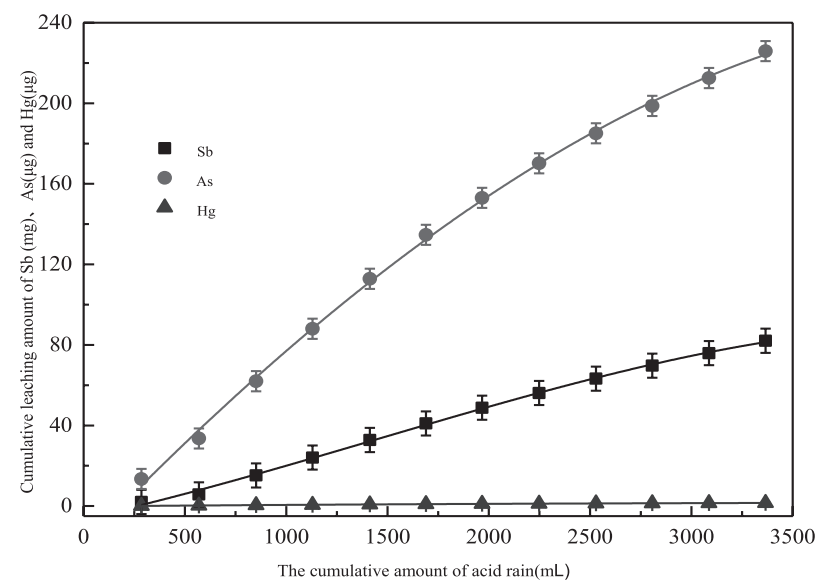

Fig. 17. Cumulative leaching data for $\mathrm{Sb}$, As, and $\mathrm{Hg}$ during heavy rain.

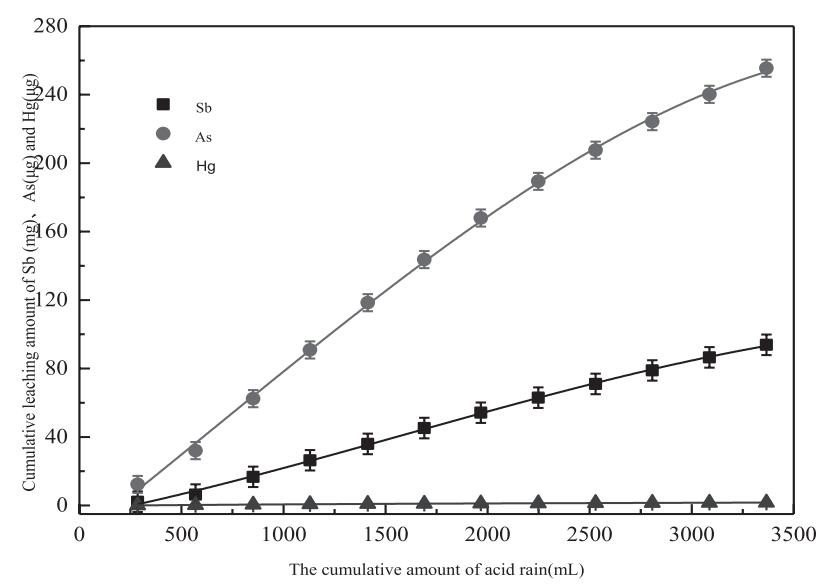

Fig. 18. Cumulative leaching data for $\mathrm{Sb}$, As, and $\mathrm{Hg}$ during moderate rain. 
loss. Consequently, the volume of water was $287 \mathrm{~mL}$ every day, the $\mathrm{pH}$ of water was 5.0.

The leaching behavior of $\mathrm{Sb}, \mathrm{As}$, and $\mathrm{Hg}$ at different rainfall intensities with time is shown in Fig. 15. The concentrations of $\mathrm{Sb}$ and $\mathrm{As}$ in the leachates peaked after 2 rainstorm days, whereas the $\mathrm{Hg}$ concentration was lowered. The concentrations of $\mathrm{Sb}, \mathrm{As}$, and $\mathrm{Hg}$ in the leachates peaked after 3 days of heavy or moderate rain, reaching the maximum and then gradually stabilizing. Comparing rainstorms with heavy and moderate rain, the hydraulic shear forces on the surface of the particles was high and thus scouring forces were also higher than

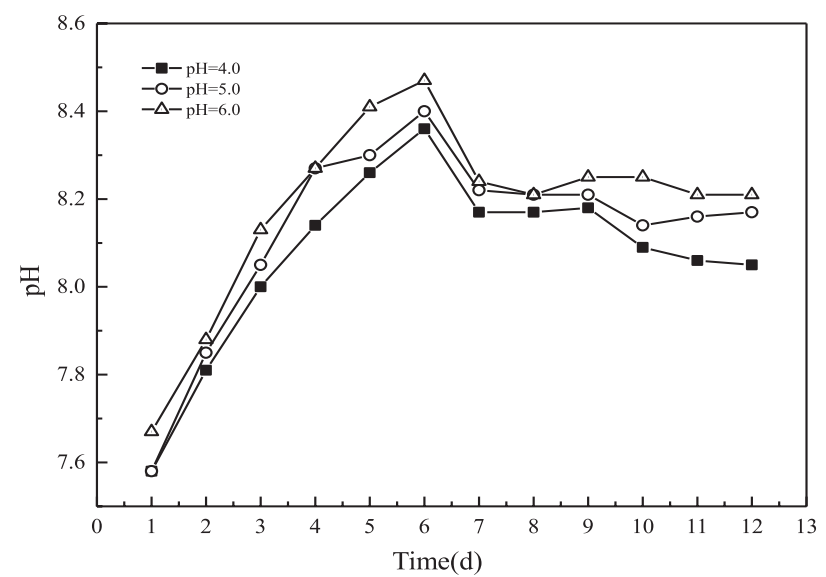

Fig. 19. $\mathrm{pH}$ value of leaching solutions vs. time for different initial $\mathrm{pH}$ solutions. in other conditions [38]. Therefore, the concentration of heavy metals in the runoff peaked early and quickly reached maximum. However, the larger intensity signs and the shorter duration with the same level of rainfall means the leaching time and oxidation precipitation will be reduced.

The leaching behavior of heavy metals depends on the rainfall intensity, and for rainstorms were $75.650 \mathrm{mg}, 214.440 \mu \mathrm{g}$, and $1.339 \mu \mathrm{g}$, for $\mathrm{Sb}$, As, and $\mathrm{Hg}$, respectively. For heavy rain, the $\mathrm{Sb}, \mathrm{As}$, and $\mathrm{Hg}$ quantities in the leachates were $82.073 \mathrm{mg}, 225.902 \mu \mathrm{g}$, and $1.535 \mu \mathrm{g}$, respectively. Finally, for moderate rain, the quantities of $\mathrm{Sb}, \mathrm{As}$, and $\mathrm{Hg}$ in the leachates were $93.894 \mathrm{mg}, 255.451 \mu \mathrm{g}$, and $1.690 \mu \mathrm{g}$, respectively. The leaching of $\mathrm{Sb}$, As, and $\mathrm{Hg}$ increased in the following order: moderate rain $>$ heavy rain $>$ rainstorm.

The leaching of heavy metals was complex and involves vertical motion, horizontal diffusion, and other physical and chemical processes. Finally, cubic polynomials better described the experimental results for the cumulative release and rainfall (Figs 16-18).

\section{Rainstorm:}

Fitting equation of Sb: $\mathrm{Y}=-6.4176+0.03384 \mathrm{X}-2.79454 \mathrm{E}$ ${ }^{6} \mathrm{X}^{2}-1.12441 \mathrm{E}^{-11} \mathrm{X}^{3}\left(\mathrm{R}^{2}=0.9998\right)$

Fitting equation of As: $\mathrm{Y}=-16.09143+0.12581 \mathrm{X}-$ $2.67666 \mathrm{E}^{-5} \mathrm{X}^{2}+2.8964 \mathrm{E}^{-9} \mathrm{X}^{3},\left(\mathrm{R}^{2}=0.9999\right)$

Fitting equation of $\mathrm{Hg}: \mathrm{Y}=-0.09502+7.22529 \mathrm{E}^{-4} \mathrm{X}-$ $1.15296 \mathrm{E}^{-7} \mathrm{X}^{2}+8.14254 \mathrm{E}^{-12} \mathrm{X}^{3}\left(\mathrm{R}^{2}=0.9998\right)$

Heavy rain:

Fitting equation of $\mathrm{Sb}: \mathrm{Y}=-6.22899+0.02235 \mathrm{X}+$ $5.07232 \mathrm{E}^{-6} \mathrm{X}^{2}-1.18142 \mathrm{E}^{-9} \mathrm{X}^{3}\left(\mathrm{R}^{2}=0.9984\right)$
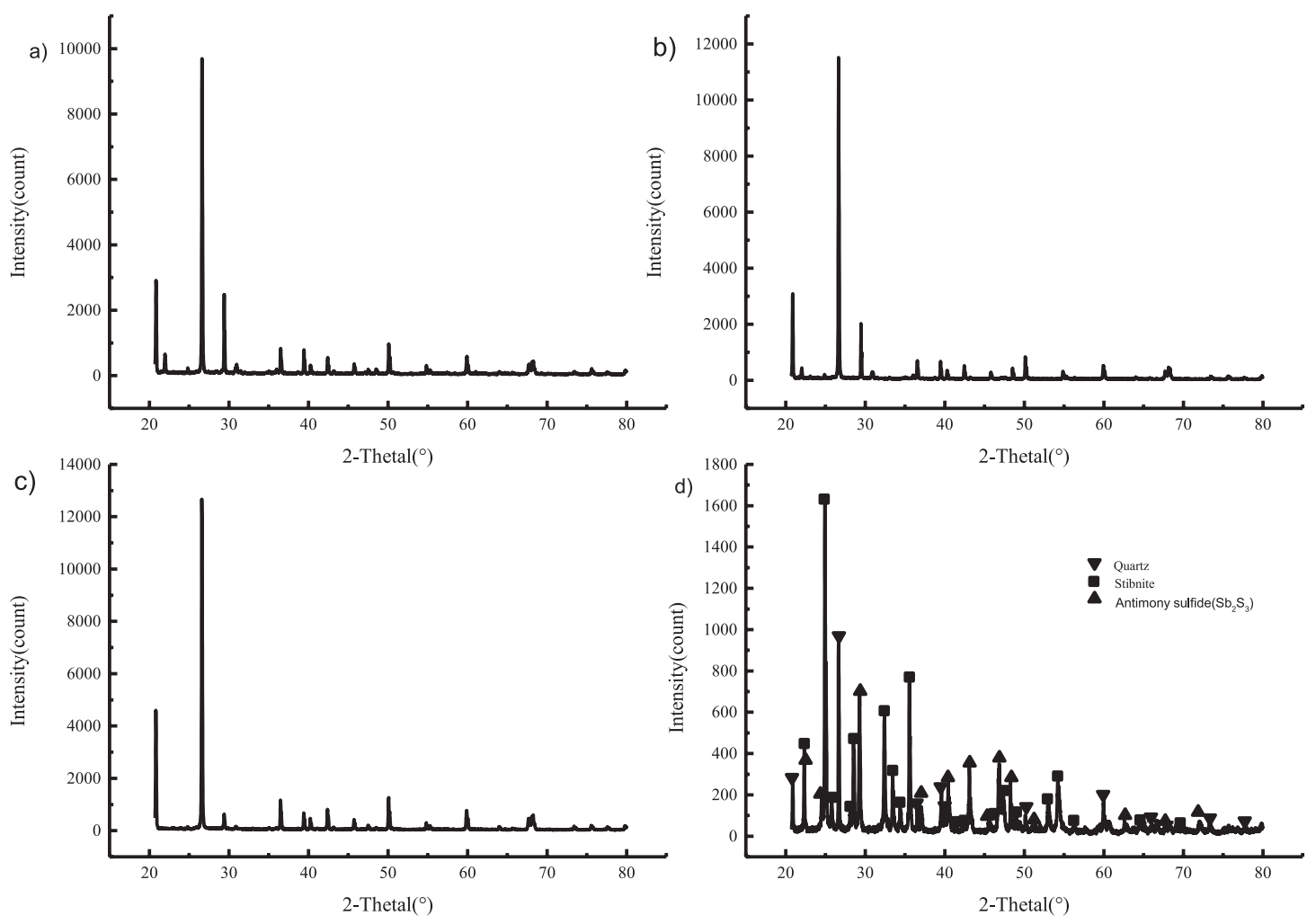

Fig. 20. XRD patterns of leaching residues at a) $\mathrm{pH} 4.0$, b) $\mathrm{pH} 5.0$, c) $\mathrm{pH} 6.0$, and d) slag. 
Table 3. Slag composition before and after leaching ( $\%$, mass fraction).

\begin{tabular}{|c|c|c|c|c|c|c|c|c|c|c|c|c|c|c|c|}
\hline & $\mathrm{O}$ & $\mathrm{Si}$ & $\mathrm{Al}$ & $\mathrm{Ca}$ & $\mathrm{S}$ & $\mathrm{Pb}$ & $\mathrm{Cd}$ & $\mathrm{Sb}$ & $\mathrm{As}$ & $\mathrm{Hg}$ & $\mathrm{Cu}$ & $\mathrm{Mn}$ & $\mathrm{K}$ & $\mathrm{Fe}$ & $\mathrm{Cr}$ \\
\hline Before leaching & 43.38 & 47.07 & 1.63 & 1.47 & 0.86 & 1.33 & 0.18 & 1 & 0.02 & 0.48 & 0. & 1.07 & 0.37 & 1.09 & 0.05 \\
\hline After leaching & 52.55 & 40.34 & 1.34 & 0.89 & 0.09 & 1.22 & 0.06 & 0.82 & 0.48 & 0.45 & 0.32 & 0.67 & 0.02 & 0.63 & 0.03 \\
\hline
\end{tabular}

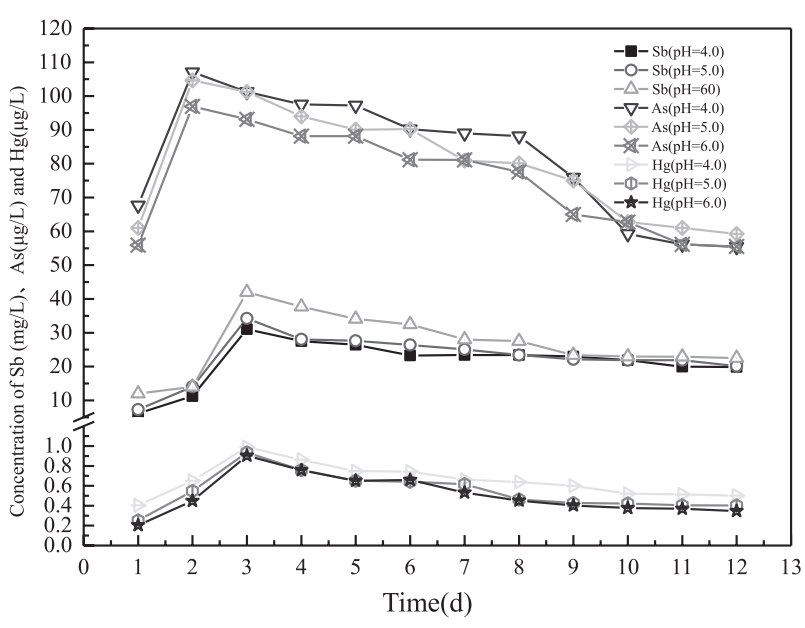

Fig. 21. Concentrations of $\mathrm{Sb}, \mathrm{As}$, and $\mathrm{Hg}$ in the leachate vs. time at different initial solution $\mathrm{pH}$.

Fitting equation of As: $\mathrm{Y}=-19.03855+0.10466 \mathrm{X}-$ $8.20287 \mathrm{E}^{-6} \mathrm{X}^{2}-4.23241 \mathrm{E}^{-10} \mathrm{X}^{3}\left(\mathrm{R}^{2}=0.9987\right)$

Fitting equation of $\mathrm{Hg}: \mathrm{Y}=-0.1726+8.40574 \mathrm{E}^{-4} \mathrm{X}-$ $1.15315 \mathrm{E}^{-7} \mathrm{X}^{2}+4.48919 \mathrm{E}^{-12} \mathrm{X}^{3}\left(\mathrm{R}^{2}=0.9981\right)$

Moderate rain:

Fitting equation of $\mathrm{Sb}: \mathrm{Y}=-6.49908+0.02345 \mathrm{X}+$ $6.22811 \mathrm{E}^{-6} \mathrm{X}^{2}-1.30453 \mathrm{E}^{-9} \mathrm{X}^{3}\left(\mathrm{R}^{2}=0.9987\right)$

Fitting equation of As: $\mathrm{Y}=-18.13551+0.09377 \mathrm{X}+$ $5.3482 \mathrm{E}^{-6} \mathrm{X}^{2}-2.74515 \mathrm{E}^{-9} \mathrm{X}^{3}\left(\mathrm{R}^{2}=0.9980\right)$

Fitting equation of $\mathrm{Hg}: \mathrm{Y}=-0.26782+0.00112 \mathrm{X}-$

$2.47942 \mathrm{E}^{-7} \mathrm{X}^{2}+2.64602 \mathrm{E}^{-11} \mathrm{X}^{3}\left(\mathrm{R}^{2}=0.9967\right)$

\section{Leaching Characteristics of $\mathrm{Sb}, \mathrm{As}$, and $\mathrm{Hg}$ at Different $\mathrm{pH}$}

The evolution of $\mathrm{pH}$ in the leaching solutions with time is shown in Fig. 19. The $\mathrm{pH}$ of the leachates increased in the first six days, then decreased, and finally stabilized. The high $\mathrm{pH}$ values are due to the strong neutralizing ability of alkaline minerals, such as quartz, in the tailings [39]. The leachate $\mathrm{pH}$ values influenced the metals precipitation to an extent $[36,40]$.

In Fig. 20, the diffraction peaks of quartz and calcite decreased after leaching and this is consistent with leaching affecting stibnite, antimony sulfide, and quartz. From the energy spectrum in Table 3 , it was inferred that $\mathrm{Al}^{3+}$ in the tailings reacts with $\mathrm{OH}^{-}$and sulfide minerals (FeAsS) oxidizing to produce $\mathrm{H}_{2} \mathrm{SO}_{4}$ and $\mathrm{Fe}_{2}\left(\mathrm{SO}_{4}\right)_{3}$ [41], decreasing the $\mathrm{pH}$ of the leaching solution [42].

The concentrations of $\mathrm{Sb}, \mathrm{As}$, and $\mathrm{Hg}$ in the leachates with time at different initial $\mathrm{pH}$ are shown in Fig. 21.
The $\mathrm{Sb}$, $\mathrm{As}$, and $\mathrm{Hg}$ concentrations rapidly reached maximum within one to 3 days. This may be due to the destruction of the particle surface structure and the oxidation of phases, such as $\mathrm{Sb}_{2} \mathrm{~S}_{3}$ to $\mathrm{SbO}_{3}^{-}$, to form complexes that enter the leachate [43]. $\mathrm{Al}^{3+}$ and $\mathrm{Fe}^{3+}$ reacted with the weak alkaline solutions to produce colloids that cover the surface of the slag particles, preventing further oxidation. Compared with $\mathrm{As}$ and $\mathrm{Hg}$, the concentration of $\mathrm{Sb}$ changes inversely, which was related to $\mathrm{Sb}$ having both sexes.

From Fig. 21, the change trend of concentrations about $\mathrm{As}$ and $\mathrm{Hg}$ were same, and concentrations of As under initial $\mathrm{pH}=4.0, \mathrm{pH}=5.0$, and $\mathrm{pH}=6.0$ leaching solution reached the maximums after 2 days, which were $107.097 \mu \mathrm{g} \cdot \mathrm{L}^{-1}, 104.608 \mu \mathrm{g} \cdot \mathrm{L}^{-1}$, and $96.973 \mu \mathrm{g} \cdot \mathrm{L}^{-1}$, respectively. The concentrations of $\mathrm{Hg}$ under initial $\mathrm{pH}=4.0, \mathrm{pH}=5.0$, and $\mathrm{pH}=6.0$ leaching solution reached maximum after 3 days: $0.989 \mu \mathrm{g} / \mathrm{L}, 0.934 \mu \mathrm{g} / \mathrm{L}$, and $0.902 \mu \mathrm{g} / \mathrm{L}$, respectively. The exchangeable phases were oxidized and fully released of heavy metals to the solutions, which made the curve appear on a downward trend and determined the final concentration of heavy metals [44].

\section{Conclusions}

The contents of $\mathrm{Sb}, \mathrm{As}, \mathrm{Hg}, \mathrm{Cd}$, and $\mathrm{Zn}$ in antimony ore tailings exceed the background values in the order of $\mathrm{Sb}>\mathrm{Cd}>\mathrm{Hg}>\mathrm{Zn}>$ As. The chemical speciation of heavy metals in the tailings was mainly due to the residual phases, whereas the content of exchangeable cations and carbonate minerals was low, but those were mainly the chemical speciation of pollution.

The leaching behaviors of $\mathrm{Sb}$, As, and $\mathrm{Hg}$ were examined with different solid-liquid ratios, particle sizes, temperatures, $\mathrm{pH}$, and rainfall intensities. In the leachates, the concentrations of $\mathrm{Sb}, \mathrm{As}$, and $\mathrm{Hg}$ increased with increasing solid-liquid ratio, decreasing particle size, and increasing temperature. Leaching as a function of rain increased in the order of moderate rain $>$ heavy rain $>$ rainstorm. The cumulative leaching of $\mathrm{Sb}$ at $\mathrm{pH} 6.0$ was higher than that at $\mathrm{pH} 4.0$ and 5.0, and the cumulative leaching of As and $\mathrm{Hg}$ increased in the order of $\mathrm{pH} 4.0>\mathrm{pH} 5.0>\mathrm{pH} 6.0$.

\section{Acknowledgements}

This work was supported by the National Natural Science Foundation of China (No. 41472328). 


\section{Conflict of Interest}

The authors declare no conflict of interest.

\section{References}

1. ELSHARJAWY A.A., AMIN A.S.. Use of cloud-point preconcentration for spectrophotometric determination of trace amounts of antimony in biological and environmental samples. Analytical Biochemistry. 492, 1, 2016.

2. FORT M., GRIMALT J.O., QUEROL X., CASAS M., SUNYER J. Evaluation of atmospheric inputs as possible sources of antimony in pregnant women from urban areas. Science of the Total Environment. 544, 391, 2016.

3. SHARIFI R., MOORE F., KESHAVARZI B. Mobility and chemical fate of arsenic and antimony in water and sediments of Sarouq River catchment, Takab geothermal field, northwest Iran[J]. Journal of Environmental Management. 170 (02), 136, 2016.

4. SUN W., XIAO E., DONG Y., TANG S., KRUMINS V., NING Z., SUN M., ZHAO Y., WU S., XIAO T. Profiling microbial community in a watershed heavily contaminated by an active antimony $(\mathrm{Sb})$ mine in Southwest China. Science of the Total Environment. 550, 297, 2016.

5. WU F., FU Z., LIU B., MO C., CHEN B., CORNS W., LIAO $\mathrm{H}$. Health risk associated with dietary co-exposure to high levels of antimony and arsenic in the world's largest antimony mine area. Science of the Total Environment. 409 (18), 3344, 2011.

6. PENG B., LIU Z., CHAI L., LIU H., YANG S., YANG B., XIANG K., LIU C. Effect of copper ions on the mercury re-emission in a simulated wet scrubber. Fuel, 2016.

7. LIU Z., WANG D., PENG B., CHAI L., LIU H., YANG S., YANG B., XIANG K., LIU C. Transport and transformation of mercury during wet flue gas cleaning process of nonferrous metal smelting. Environmental Science \& Pollution Research. 24 (28), 22494, 2017.

8. GUO X., WANG K., HE M., LIU Z., YANG H., LI S. Antimony smelting process generating solid wastes and dust: characterization and leaching behaviors. 26 (7), 1549, 2014.

9. WILSON S.C., LOCKWOOD P.V., ASHLEY P.M., TIGHE $\mathrm{M}$. The chemistry and behaviour of antimony in the soil environment with comparisons to arsenic: a critical review. Environmental Pollution. 158 (5), 1169, 2010.

10. HU X., HE M., KONG L. The leaching characteristics and changes in the leached layer of antimony-bearing ores from China. Journal of Geochemical Exploration. 176, 76, 2016.

11. LI Y., LIU Z., LIU H., PENG B. Clean strengthening reduction of lead and zinc from smelting waste slag by iron oxide. Journal of Cleaner Production. 143, 311, 2016.

12. BECH J., CORRALES I., TUME P., BARCELÓ J., DURAN P., ROCA N., POSCHENRIEDER C. Accumulation of antimony and other potentially toxic elements in plants around a former antimony mine located in the Ribes Valley (Eastern Pyrenees). Journal of Geochemical Exploration. 113 (1), 100, 2012.

13. BIVER M., SHOTYK W. Experimental study of the kinetics of ligand-promoted dissolution of stibnite (Sb2S3). Chemical Geology. 294-295 (4), 165, 2012.

14. SHTANGEEVA I., BALI R., HARRIS A. Bioavailability and toxicity of antimony [J]. Journal of Geochemical Exploration. 110 (1), 40, 2011.
15. SHTANGEEVA I., NIEMELÄ M., PERÄMÄKI P. Effects of soil amendments on antimony uptake by wheat[J]. Journal of Soils \& Sediments. 14 (4), 679, 2014.

16. 1BIVER M., SHOTYK W. Stibiconite $\left(\mathrm{Sb}_{3} \mathrm{O}_{6} \mathrm{OH}\right)$, senarmontite $\left(\mathrm{Sb}_{2} \mathrm{O}_{3}\right)$ and valentinite $\left(\mathrm{Sb}_{2} \mathrm{O}_{3}\right)$ : Dissolution rates at $\mathrm{pH} \mathrm{2-11}$ and isoelectric points. Geochimica Et Cosmochimica Acta. 109 (3), 268, 2013.

17. BIVER M., SHOTYK W. Stibnite $\left(\mathrm{Sb}_{2} \mathrm{~S}_{3}\right)$ oxidative dissolution kinetics from $\mathrm{pH} 1$ to $11[\mathrm{~J}]$. Geochimica Et Cosmochimica Acta. 79 (3), 127, 2012.

18. ZHANG R.L., ZHANG X.F., TANG S.Z., HUANG A.D. Ultrasound-assisted $\mathrm{HCl}-\mathrm{NaCl}$ leaching of lead-rich and antimony-rich oxidizing slag. Ultrasonics Sonochemistry. 27, 187, 2015.

19. REN B., ZHOU Y., HURSTHOUSE A.S. DENG R. Research on the Characteristics and Mechanism of the Cumulative Release of Antimony from an Antimony Smelting Slag Stacking Area under Rainfall Leaching. Journal of Analytical Methods in Chemistry. 2017 (4), 1, 2017.

20. REN B., ZHOU Y., MA H., DENG R., ZHANG P., HOU B. Sb release characteristics of the solid waste produced in antimony mining smelting process. Journal of Material Cycles \& Waste Management. 1-8, 2016.

21. KWONG Y.T.J., WHITLEY G., ROACH P., EPPINGER R.G., FUGE R. Natural acid rock drainage associated with black shale in the Yukon Territory, Canada. Applied Geochemistry. 24 (2), 221, 2009.

22. VERPLANCK P.L., NORDSTROM D.K., BOVE D.J., PLUMLEE G.S., RUNKEL R.L., EPPINGER R.G., FUGE R. Naturally acidic surface and ground waters draining porphyry-related mineralized areas of the Southern Rocky Mountains, Colorado and New Mexico. Applied Geochemistry. 24 (2), 255, 2009.

23. ASTA M.P., AYORA C., ROMÁN-ROSS G., CAMA J., ACERO P., GAULT A.G., CHARNOCK J.M., BARDELLI F. Natural attenuation of arsenic in the Tinto Santa Rosa acid stream (Iberian Pyritic Belt, SW Spain): The role of iron precipitates. Chemical Geology. 271 (1-2), $1,2010$.

24. MONCUR M.C., JAMBOR J.L., PTACEK C.J., BLOWES D.W., THOMPSON A., VAUGHAN D.J. Mine drainage from the weathering of sulfide minerals and magnetite. Applied Geochemistry. 24 (12), 2362, 2009.

25. U.S. Geological Survey, Mineral Commodity Summaries 2013. Washington, 2013.

26. HE M., WANG X., WU F., FU Z. Antimony pollution in China. The Science of the total environment. 421-422 (3), 41, 2012.

27. M H. Distribution and phytoavailability of antimony at an antimony mining and smelting area, Hunan, China. Environmental Geochemistry and Health. 29 (3), 209, 2007.

28. LI J., WEI Y., ZHAO L., ZHANG J., SHANGGUAN Y., LI F., HOU H. Bioaccessibility of antimony and arsenic in highly polluted soils of the mine area and health risk assessment associated with oral ingestion exposure. Ecotoxicology \& Environmental Safety. 110 (110), 308, 2014.

29. CIDU R., BIDDAU R., DORE E., VACCA A.,MARINI L. Antimony in the soil-water-plant system at the Su Suergiu abandoned mine (Sardinia, Italy): Strategies to mitigate contamination. Science of the Total Environment. 497-498 (1), 319, 2014

30. WANG X., HE M., XI J., LU X. Antimony distribution and mobility in rivers around the world's largest antimony mine 
of Xikuangshan, Hunan Province, China. Microchemical Journal. 97 (1), 4, 2011.

31. TIGHE M., LOCKWOOD P., WILSON S. Adsorption of antimony $(\mathrm{V})$ by floodplain soils, amorphous iron(III) hydroxide and humic acid. J Environ Monit. 7 (12), 1177, 2005.

32. MITSUNOBU S., MURAMATSU C., WATANABE K., SAKATA M. Behavior of antimony(V) during the transformation of ferrihydrite and its environmental implications. Environmental Science \& Technology. 47 (17), 9660, 2013

33. TESSIER A., CAMPBELL P.G.C., BISSON M. Particulate trace metal speciation in stream sediments and relationships with grain size: Implications for geochemical exploration[J]. Journal of Geochemical Exploration. 16 (2), 77, 1982.

34. LEE P.K., YU S. Lead isotopes combined with a sequential extraction procedure for source apportionment in the dry deposition of Asian dust and non-Asian dust. Environmental Pollution. 210, 65, 2016.

35. ALABED S.R., HAGEMAN P.L., JEGADEESAN G., MADHAVAN N., ALLEN D. Comparative evaluation of short-term leach tests for heavy metal release from mineral processing waste. Science of the Total Environment. 364 (1-3), 14, 2006.

36. ZHOU S., LI N., REN B., ZHANG P. Release Law of Sb, As, and $\mathrm{Hg}$ in Antimony Smelting Slag Under Simulated Acid Rain. Polish Journal of Environmental Studies., 26 (2), 925, 2017.

37. ZHAO G.H., LUO X.Z., CHEN G., ZHAO Y.J. A longterm static immersion experiment on the leaching behavior of heavy metals from waste printed circuit boards. Environmental Science Processes \& Impacts. 16 (8), 1967, 2014.

38. LIU H., LEI T.W., ZHAO J., YUAN C.P., FAN Y.T., QU L.Q. Effects of rainfall intensity and antecedent soil water content on soil infiltrability under rainfall conditions using the run off-on-out method[J]. Journal of Hydrology. 396 (1), 24, 2011.

39. QAJAR J., ARNS C.H. Characterization of reactive flow-induced evolution of carbonate rocks using digital core analysis- part 1: Assessment of pore-scale mineral dissolution and deposition. Journal of Contaminant Hydrology. 192, 60, 2016.

40. POTYSZ A., KIERCZAK J., FUCHS Y., GRYBOS M., GUIBAUD G., LENS P.N.L., HULLEBUSCH E.D.V. Characterization and $\mathrm{pH}$-dependent leaching behaviour of historical and modern copper slags. Journal of Geochemical Exploration. 160, 1, 2016.

41. RIVERA-VASQUEZ B.F., DIXON D. Rapid atmospheric leaching of enargite in acidic ferric sulfate media. Hydrometallurgy. 152, 149, 2015.

42. LI H., WANG Z., YANG Z., CHAI L., LIAO Y. Static and Dynamic Leaching of Chromium(VI) from ChromiumContaining Slag. Environmental Engineering Science. 29 (6), 426, 2012.

43. HU X., HE M., KONG L. Photopromoted oxidative dissolution of stibnite. Applied Geochemistry. 61, 53, 2015.

44. KYZAS G.Z., MATIS K.A. Methods of arsenic wastes recycling: Focus on flotation. Journal of Molecular Liquids. 214, 37, 2016. 
